\title{
Effect of Incorporated Blower Improved Smoking Kiln and Traditional Smoking Kiln on Processing, Preservation and Nutrient Qualities of Clarias Gariepinus
}

\author{
Waindu Chinda* \\ Department of Fisheries Production Technology, College of Agriculture, Nigeria
}

Submission: February 18, 2019; Published: April 04, 2019

Corresponding author: Waindu Chinda, Department of Fisheries Production Technology, College of Agriculture, Ganye, Adamawa state, Nigeria

\begin{abstract}
The research was carried out to compare effect of incorporated blower improved smoking kiln and traditional smoking kiln on the processing, preservation and nutrient qualities of Clarias gariepinus. The result showed that the time taken to smoke Clarias gariepinus using improved smoking kiln was 5 hours 5 minutes to reduce weight of Clarias gariepinus from $3.10 \mathrm{~kg}$ to $1.50 \mathrm{~kg}$ moisture loss of $0.32 \mathrm{l} / \mathrm{h}$. The time taken to smoke Clarias gariepinus using traditional smoking kiln was 7 hours 30 minutes to reduce the weight from $2.85 \mathrm{~kg}$ to $1.25 \mathrm{~kg}$ moisture loss of $0.22 \mathrm{l} / \mathrm{h}$. The fish samples were analyzed for proximate composition. The results of the organoleptic analysis indicate that the smoked fish samples using the two processors had good color, texture, flavor, taste and overall acceptability. The use of improved smoking kiln with blower indicates the most efficient use in smoking fish under proper hygiene and is therefore recommended.
\end{abstract}

Keywords: Traditional smoking kiln; Improved smoking kiln with blower; Nutrient; Sensory evaluation; Clarias gariepinus

\section{Introduction}

Fish is hig1y susceptible to deterioration without any preservative or processing measures [1]. Due to its chemical composition, it is a perishable food material which flavor and texture changes rapidly during storage after death. Fish harvesting, handling, processing and distribution provides livelihood for millions of people as well as providing foreign exchange to many countries [2]. In many rural fishing communities, the infrastructures for post-harvest processing and preservation of fish are inadequate. The post-harvest management assures the maximum benefit to man of harvested fish with little or no losses. To promote the added value of fish once it is removed from water by changing its state, its condition and the environment of handling; it is important for the fact that all the efforts of production (capture or culture) will only become meaningful when the produce (fish and fish product) have become ultimately beneficial to man. The traditional smoking kiln lack control over fire temperature and smoke production, inefficient use of fuel. There is need to improve smoking kiln with more control over the temperature and hence less chance of charring the fish.

\section{Materials and Methods}

The Research was carried out in the Department of Fisheries, School of Agriculture and Agricultural Technology, Modibbo Adama University of technology Yola, Adamawa State.

\section{Fish Smoking kilns}

Traditional Smoking Kiln: The traditional smoking kiln of perforated half oil drum of 1 meter in height, with grating on top the grating made from steel, fish were laid on grill and the charcoal burnt in the fire box beneath it, to generate heat and smoke (Plate 1).

Materials for Constructing Improved Smoking Kiln with Blower: Improved smoking kiln incorporated with blower having turn on and off button as well as regulator was constructed using galvanized steel sheet for outer while stainless steel sheet was used inside. Height of 1.5 meters, length 0.50 meter and width of 1 meter. Strong angle bar iron was used for the construction of the stand which formed the main stand and support for the smoking kiln. Fixed at each angle of the kiln for strengthening. Inner chamber has three (3) carriers of fish trays. The trays can be exchange when the need arise. It has a single closet door. The bottom has a fire box in-built while the turn on and off button as well as the regulator are outside the kiln and is detachable as they are on long pipe and with blower which fans the charcoal in fire box inside. The ignited charcoal to produce the required heat temperature for smoke drying of the fish inside the kiln. The blower is powered by four (4) torch light dry cell battery as there is wiring which connects the fan attached on radio motor which rotates the fan 
blade to blow air into the fire box. The velocity is regulated by the regulator because the regulator determines the velocity and rate of heat emission

\section{Construction of Improved Smoking Kiln with Blower}

Frame: Made up of angle iron, the angle irons were cut and welded together to form the stand and support for the kiln with $0.50 \mathrm{~m}$ by $1 \mathrm{~m}$ by 1.5 galvanized sheet as the length, width, height respectively (Figure 1)

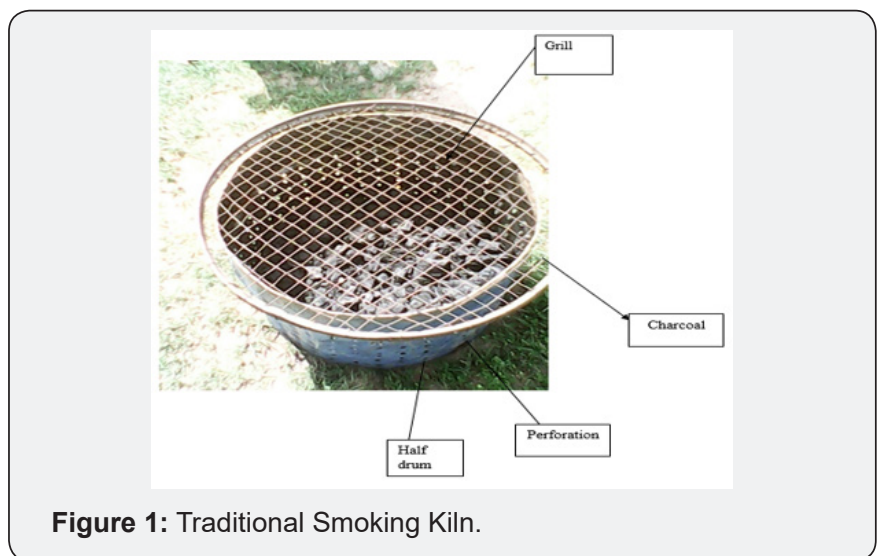

Fish tray: These are flat grill into which the fish are loaded and smoke. It is constructed with metal sheet and wire mesh which form wire trays and they are removable.

Charcoal tray: This is the container for burning the charcoal to provide energy for smoking the fish, it was constructed from metal sheets $1 \mathrm{~mm}$ thick. The sheet was perforated at the base.

The blower: The blower is powered by four (4) torch light dry cell battery as there is wiring which connects the fan attached on radio motor which rotates the fan blade to blow air into the fire box. The velocity is regulated by the regulator because the regulator determines the velocity and rate of heat emission.

A smoking kiln assembly: The various components of the smoking kiln were either fastened using bolts, pinned or welded and assembled as shown in Plate II.

\section{Operational Techniques}

The fish were fed into the fish tray. The charcoal was lit using kerosene and matches and the burning charcoal was fan by the blower to supply the heat which dries the fish and smokes that envelope the fish serve as a preservative. The blower drives the fan which supplies air to facilitate the burning of the charcoal. The ashes drop out through the perforation at the base of the charcoal box. To control the heat transfer to the fish, the blower is turn off.

\section{Collection of and Transportation of Samples}

Twenty samples of Clarias gariepinus fish weighing $5.95 \mathrm{~kg}$ was bought from Boronji Jimeta fishing community along River Benue water course and were transported to the Department of Fisheries, Modibbo Adama University of Technology Yola in 50 litres plastic jerry can.

\section{Preparation of Clarias gariepinus}

The fish samples were kept in a plastic bowl and apply $30 \%$ salt solution for 30 minutes before washing it in the same saline solution to remove the slime. The sample fish was later rinsed with plenty clean water until there was no more slime left. The fish abdomen was slit open from the anal opening toward the head and the intestine removed. The fish sample was then washed thoroughly with clean water and allowed to drip (Figure 2) Performance evaluation. African catfish; (Clarias species) were procured from Boronji landing site fish market Jimeta. The samples were thoroughly washed using saline solution of $30 \%$ of salt to wash the Clarias gariepinus. Then allowed to drip and dried for an hour under the sun. The charcoal in both the half drum smoking kiln and improved smoking kiln was first ignited using kerosene and matches, the ignited charcoal could burn for 10 to 15 minutes to allow the kerosene odor to be exhausted, then more charcoal was added to the burning charcoal.

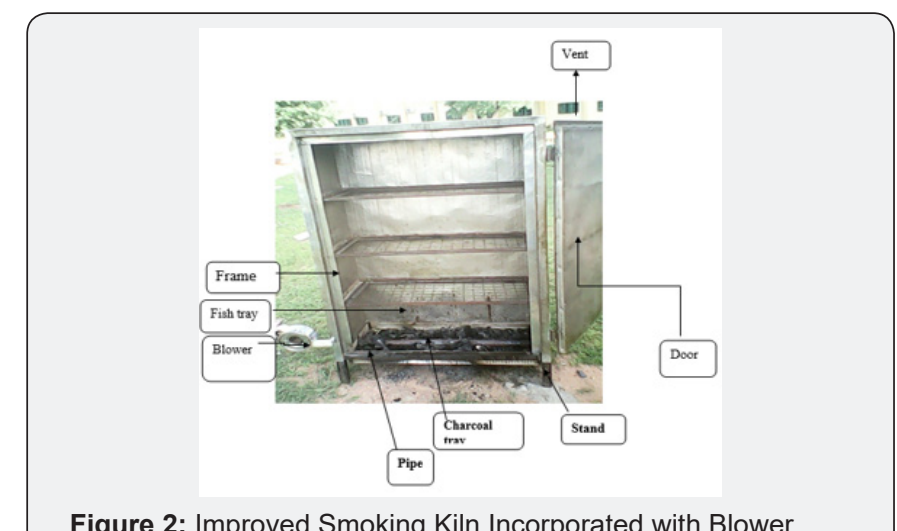

Figure 2: Improved Smoking Kiln Incorporated with Blower.

The Clarias gariepinus after dripping and sun drying was weighed (initial weight). The fish samples were arranged on both fish tray of half drum smoking kiln and improved smoking kiln and put into the smoking kiln and on the grill of the half drum. As the charcoal was burning the blower was fanning the charcoal to supply a constant heat. While the half drum smoking kiln depend on the natural air blow to maintain its heat which is not constant. During the smoking, the side of the fish facing the burning charcoal was changed routinely by turning the fish upside down. The time taken for the smoking was the total time taken including the time of changing the position of the fish. After smoking and determination of final moisture content the fish, allowed to cool and kept in polythene bag to determine its storage life for four weeks.

\section{Sensory Evaluation}

The sensory evaluation of the two samples was carried out using 10-man panel through a seven (7) point hedonic scale [3] grading sheets to evaluate texture, colors, taste, flavor and general acceptability. From the score sheets used 1. Represents dislike very much 2 . Dislike moderately 3 . Dislike slightly 4 . Neither like nor dislike 5 . Like slightly 6 . Like moderately 7 . Like very much. The smoked fish was analyzed for quantitative and qualitative for characteristics such as before and after smoking weight, drying time proximate values and shelf life. 


\section{Laboratory and Data Analysis}

The proximate analysis of the two samples for moisture, ash and carbohydrate content were determined as described by AOAC [4] crude protein, fibre and fat contents were determined using the methods described by Pearson [5]. Data generated was subjected to standard statistical analysis using computer software (graphpad instat) The result were presented as mean Standard Deviation or Standard Error of Mean. Differences between mean values were analyzed using student t-test and level of significance were considered at $\mathrm{p}<0.05$ test and correlation using to ascertain the significance

\section{Results}

The performance of the two processors were compared based on their operations. The assembled improved smoking kiln incorporated with blower was rigid and operated smoothly with little effort needed to operate the blower which fans the burning charcoal. While the traditional smoking kiln require more effort for the charcoal to burn. The efficiency of the two smoking kilns in smoking Clasias gariepinus is presented on which shows that within time frame of average 5 hours 5 minutes the moisture content of Clarias (African catfish) was reduced to safe moisture content. The time taken for smoking depends on the weight of fish, the initial moisture content, the fat content of the fish and the uniformity and intensity of heat supplied. The traditional smoking kiln took more than 7hours in addition to the other labor stress for the fish to dry. The results showed that the time taken to smoke Clarias gariepinus using improved smoking kiln was 5-hour 5minutes which reduces weight of Clarias garepinus from $3.10 \mathrm{~kg}$ to $1.50 \mathrm{~kg}$ moisture loss of $0.32 \mathrm{l} / \mathrm{h}$ This result opines that, much time is required to smoke fish using traditional smoking than the improved smoking kiln.

Table 1: Efficiency of the Smoking kiln in Processing Clarias gariepinus.

\begin{tabular}{|c|c|c|c|c|}
\hline Smoking & Initial \\
kilns & weight (kg) & $\begin{array}{c}\text { Time taken } \\
\text { to smoke } \\
\text { the fish (h) }\end{array}$ & $\begin{array}{c}\text { Final } \\
\text { weight (kg) }\end{array}$ & $\begin{array}{c}\text { Smoking } \\
\text { kiln effi- } \\
\text { ciency }\end{array}$ \\
\hline $\begin{array}{c}\text { Improved } \\
\text { smoking } \\
\text { kiln }\end{array}$ & $3.10^{\mathrm{a}}$ & $5.05^{\mathrm{b}}$ & $1.50^{\mathrm{a}}$ & $0.32 \mathrm{~g} / \mathrm{h}^{\mathrm{a}}$ \\
\hline $\begin{array}{c}\text { Traditional } \\
\text { smoking } \\
\text { kiln }\end{array}$ & $2.85^{\mathrm{a}}$ & $7.30^{\mathrm{a}}$ & $1.25^{\mathrm{a}}$ & $0.22 \mathrm{~g} / \mathrm{h}^{\mathrm{b}}$ \\
\hline
\end{tabular}

Means on the same column with different superscripts are significantly different $(p<0.05)$

The initial ( $1^{\text {st }}$ week) percent of moisture were found $10.85 \%$ and $14.85 \%$ for smoked Clarias in two smoking kilns while there was gradual decrease in the moisture content of Clarias $10.56 \%$ and $13.60 \%$ in the $\left(2^{\text {nd }}\right.$ week). The result indicates that the crude protein content increased in the smoked fish samples initial $\left(1^{\text {st }}\right.$ week) Clarias $57.88 \%$ and $56.66 \%$ (Table 1 ) while in the $\left(2^{\text {nd }}\right.$ week) Clarias $58.70 \%$ and $57.04 \%$ respectively for the two kilns. The was increase in fat content with decrease in moisture content, in Clarias $17.20 \%$ and $18.00 \%$ in the ( $1^{\text {st }}$ week) (Table 2)
The mean sensory evaluation of the smoked fish species using improved smoking kiln incorporated with blower and traditional smoking kiln are presented in table 3. The result before storage showed that the improved smoking kiln smoked Clarias gariepinus has higher taste than the traditional smoking kiln with mean value of 6.2 in terms of taste while tradition has mean value of 5.7 and the lowest mean value mean of 4.8 recorded for Clarias gariepinus for fish smoked using traditional.The high mean value for texture was obtained from Clarias gariepinus of 5.4 smoked with traditional smoking kiln mean value of 5.1 texture from Clarias gariepinus smoked with improved smoking kiln. While overall acceptability 5.7 from improved smoking kiln. Color of 5.6 was Clarias smoked with improved smoking kiln while tradition smoking kiln 5.5. The high flavor mean value of 5.8 from improved while 5.4 from traditional smoking kilns (Table 3).

Table 2: Percentage proximate compositions of smoked Clarias gariepinus using ISK and TSK.

\begin{tabular}{|c|c|c|c|c|c|c|}
\hline \multirow[t]{2}{*}{ Parameter } & \multicolumn{2}{|c|}{ Week 1} & \multicolumn{2}{|c|}{ Week 2} & \multicolumn{2}{|c|}{ Week 3} \\
\hline & ISK & TSK & ISK & TSK & ISK & TSK \\
\hline Crude Protein & $57.88^{\mathrm{a}}$ & $56.66^{\mathrm{b}}$ & $58.7^{\mathrm{c}}$ & $57.04^{\mathrm{b}}$ & $58.82^{a}$ & $57.5^{b}$ \\
\hline Crude Fat & $17.2^{\mathrm{c}}$ & $18^{\mathrm{a}}$ & $\begin{array}{c}18.96 \\
c\end{array}$ & $17.85^{\mathrm{c}}$ & 20.24 & $19.1^{\mathrm{c}}$ \\
\hline Crude Fibre & $1.63^{\mathrm{a}}$ & $1.65^{b}$ & $1.5^{c}$ & $1.13^{\mathrm{b}}$ & $1.43^{\mathrm{a}}$ & $1.03^{\mathrm{a}}$ \\
\hline Ash & $9.9^{\text {a }}$ & $10.23^{c}$ & $8.75^{c}$ & $8.1^{b}$ & $8.54^{\mathrm{b}}$ & $8.5^{b}$ \\
\hline Carbohydrate & $2.53^{\mathrm{a}}$ & $2.45^{\mathrm{a}}$ & $1.53^{b}$ & $1.03^{\mathrm{a}}$ & $0.58^{\mathrm{c}}$ & $0.27^{c}$ \\
\hline Moisture & $10.84^{\mathrm{a}}$ & $\underset{\mathrm{a}}{11.01}$ & $\underset{c}{10.56}$ & $14.84^{\mathrm{b}}$ & $10.39^{b}$ & $13.6^{b}$ \\
\hline Dry Matter & $89.5^{\mathrm{a}}$ & $88.99^{c}$ & $\underset{\mathrm{b}}{89.44}$ & $85.15^{b}$ & $89.61^{\mathrm{a}}$ & $86.4^{c}$ \\
\hline
\end{tabular}

Means with different superscripts are significantly different $(p<0.05)$

Table 3: Mean sensory evaluation of smoked Clarias gariepinus using improved smoking kiln and traditional smoking kiln.

\begin{tabular}{|c|c|c|}
\hline \multirow{2}{*}{ Sensory Qualities } & \multicolumn{2}{|c|}{ Smoking kilns } \\
\cline { 2 - 3 } & Improved & Traditional \\
\hline Texture & $5.1 \pm 0.1^{\mathrm{a}}$ & $5.4 \pm 0.22^{\mathrm{b}}$ \\
\hline Color & $5.6 \pm 0.23^{\mathrm{a}}$ & $5.5 \pm 0.54^{\mathrm{a}}$ \\
\hline Taste & $6.2 \pm 0.2^{\mathrm{a}}$ & $5.7 \pm 0.15^{\mathrm{b}}$ \\
\hline Flavor & $5.8 \pm 0.25^{\mathrm{a}}$ & $5.4 \pm 0.27^{\mathrm{b}}$ \\
\hline Overall Acceptability & $5.7 \pm 0.21^{\mathrm{a}}$ & $5.5 \pm 0.34^{\mathrm{b}}$ \\
\hline
\end{tabular}

Means with different superscripts are significantly different $(p<0.05)$

\section{Discussion}

Fish were smoked using two kilns, improved smoking kiln incorporated with blower and traditional smoking kiln. The two different kilns were tested with Clarias gariepinus, considering smoking as one of the most popular method of processing fish in the developing countries as reported by [6]. Table 1 shows that within the time frame of averagely 5 hours 5 minutes using improved smoking kiln the moisture content of each set of the fish sample was reduced to a safe moisture content this is like the 
result obtained by [7]. Generally, the main aim of smoking fish according to Tobor [8], Clucas [9] \& Eyo [10] is to reduce the moisture content of fish to about $15-20 \%$. This is to make the conditions in the fish that allows for spoilage organism and chemical activities in the fish to be reduced to minimum. The moisture contents of the smoked Clarias gariepinus of $10.39 \%$ was observed in the fish smoked with improved smoking kiln while $13.60 \%$ in fish smoked using traditional smoking kiln.

The moisture content of fish smoked with improved smoking kiln and traditional smoking kiln showed no significant difference ( $p>0.05)$ in the amount of moisture lost for both the kilns. However, the time taken for smoking as stated earlier depends on the weight and size of fish and, the initial moisture content, the fat content of the fish and the uniformity and intensity of heat supplied. The use of the improved smoking kiln incorporated with blower is found to be efficient when compared to the traditional smoking kiln that takes almost 7 hours in addition to the other labour stresses and drudgery. Fish protein is of high quality and contains enough all the essential amino acids required by the body for growth, maintenance of lean muscle tissue and active metabolism [8].

In this study, the protein content increased in smoked Clarias gariepinus. Which indicated that protein nitrogen was not lost during smoke-drying [11-13]. Stated that the increase in crude protein level resulted in concentrating crude protein components of fish. This concentration was result from the loss of moisture by the smoking process as reported by Koral et al. [14]. Percentage Proteins were found to vary from $1^{\text {st }}$ week to $2^{\text {nd }}$ week and $3^{\text {rd }}$ week there was increase in protein in both smoked fishes using ISK and TSK respectively during storage at room temperature. The protein content increased significantly with the time due to lost in moisture [15] The proximate crude protein composition of both fish smoked with improved smoking kiln and traditional smoking kiln was encouraging. However, the relatively high percentage crude protein could be attributed to the fact that the fishes are good source of pure protein as reported by [16,17].

Fish is widely accepted because of its high palatability, low cholesterol and tender flesh, however, many consumers eat fish because of its nutritional value. It is therefore necessary to make information available to consumers and fishery workers on the nutritional contribution of some fish species in their daily diets [18]. The result of the crude protein indicated that there was no significant difference $(p<0.05)$ between fish smoked using improved smoking kiln incorporated with blower and traditional smoking kiln this could be as a result of the uniformity in heat supply and its intensity in the closed charcoal chamber. This is due to their smoking duration. The crude fibre was higher in traditional smoked fish Clarias gariepinus 1.65\%, compared to improved smoking kiln Clarias gariepinus 1.03\%.

The term or period a product may be stored before a specific element of the product makes it unsuitable for use or consumption". This element could be of biological or physicochemical nature. The most important contribution of sensory attribute to eating quality was tenderness with flavor and juiciness [19]. Factors that influence the quality of smoked fish products include; the properties of fish flesh, maturity, age, sex, seasonal variations and factors involved in the smoking procedure such as wood type, composition of smoke, temperature, humidity, velocity and density of the smoke $[20,21]$. Sensory evaluation (score) was carried out using both train and untrained panel of 10 following 7-points ascending scale to evaluate texture, color, taste, flavor and general acceptability. Smoked fish is highly desirable because of its enhanced flavor and texture in fish in addition to the protection offered by smoking against microbial, enzymatic and chemical deteriorative alteration.

The smoke determines the color which is one of the qualities that attracts consumers, the color ranges from black, dark brown golden brown or light brown to dirty white [22]. At the beginning of storage all sensory parameters of these two samples were rated as good based on the grading scale. The highest mean of general acceptability score was found Clarias gariepinus with mean of 5.7 in the first day after smoking. This agreed with the findings of [23]. In all the sensory qualities examined, the smoked Clarias scored above average, which indicates that they might still be acceptable in 21 days. The sensory attributes as observed by the response of the taste panel reveals that people have preference to smoked fish samples which agreed with earlier work by Frazier and Westoff [24] which states that fish smoked with firewood had better color, taste and flavor due to the presence of phenolic compounds in the smoked. However, is advisable that fish should be smoked using charcoal than firewood as it has been observed that charcoal have undergone proper combustion which has reduced the amount of smoked lading with phenolipic compounds that have been said to be carcinogens [25]. The fishes smoked using improved smoking kiln has the highest taste in Clarias gariepinus 6.2\% while traditional smoking kiln Clarias gariepinus has 5.7\% and were not significantly different $(\mathrm{p}<0.05)$ in terms of sensory evaluation.

\section{References}

1. Okonta A A, Ekelemu J K (2005) A preliminary study of MicroOrganisms associated with fish spoilage in Asaba, Southern Nigeria. Proceedings of the $20^{\text {th }}$ Annual conference of fisheries society of Nigeria (FISON), Port-Harcourt, pp. 557-560

2. Al Jufaili M S, Opara L U (2006) Status of fisheries post-harvest industry in the Sultanate of Oman: Part 1. Journal of Fisheries International 1(2): 144-149.

3. Iwe MO (2002) Handbook of sensory methods and analysis. Rejoint communication Services Ltd, Nigeria.

4. AOAC (2005) Official Methods of Analysis In: $18^{\text {th }}$ edition (edn). Association of Official Analytical, Chemists International. Maryland, USA.

5. Pearson D (1976) The chemical analysis of foods. In: $7^{\text {th }}$ (Edn). Churchill Livingstone, London, UK, p. 3-4.

6. Eyo A A (2000) fish processing technology in the tropic. In: University of Ibadan Press, Nigeria, pp. 165-168. 
7. Ikenweiwe N B, Bolaji B O, Bolaji GA (2010) Fabrication and Performance Assessment of a Locally Developed Fish Smoking Kiln Ozean. Journal of Applied Science 3(4): 363-369.

8. Talabi O (1995) The influence of traditional handling methods on the quality of processed fish in Nigeria, proceeding of the conference on the handling, processing and marketing of tropical product institute, London, UK.

9. Clucas IJ (1982) Fish Handling, Preservation and Processing in the Tropics. In: Part II Report on the Tropical Produce Research Institute London, UK, p. 78-80.

10. Eyo AA (1993) Traditional and improved fish handling, preservation, and processing Techniques. paper presented at national workshop on fish processing, storage, marketing and utilization.

11. Puwastein P Judprasong, K Kettwan, E Vasanuchitt K, Nakngamanong Y Bhattacharjee L (1999) Proximate composition of rawand cooked thai freshwater and marine fish. J food composition anal 12: 9-16.

12. TaoW, Lunchun M (2008) Influence of hot air drying and microwave drying on nutritional and odorous properties of grass carp (ctenopharyngodon idellus) fillets. Foodchem 110(3): 647-653.

13. Komulu-Johnson CA, Aladetohun NF, Ndimele PE (2010) The effect of smoking on the nutritional qualities and shelf-life of clarius gariepinus (BURCHEL 1822). African Journal of Biotechnology 9: 73-76.

14. Koral S, Kose S, Tufan B (2009) Investigating the quality changes of raw and hot smoked garfish (Belone belone euxini, Gunther.1866) at ambient and refrigerated temperatures. Turkish Journal of fish Aquatic Science 9: 55-58.

15. Hassan MN, Rahman M, Hossain MM, Nowsad AAKM, Hossain MB (2013) Post-Harvest loss and shelf-life of traditional smoked shrimp products produced in Bangladesh. World J of fish and marine science 5(1): 14-19

16. Fawole 00, Ogundinan MA, yandiran TA A, Olugunju OF (2007) Proximate and mineral composition in some selected fresh water fishes in Nigeria. Internet Journal of food Safety 9: 52-55.
17. Sogbesan OA, Ibrahim P (2017) Assessment of Smoked Fish Quality using two smoking kilns and hybrid solar dryer on some commercial fish species in Yola, Nigeria. Journal of Animal Research and Nutrition 2(1): 6 .

18. Adewoye SO, Fawole 00, Omotosho JS (2003) Concentration of selected elements in some fresh water fishes in Nigeria. Science Focus 4: 106-108

19. Safari E, Forgarly N M, Ferrier GR, Hopkings LD, Gilmour (2001) Diverselamb genotypes. Eating quality and the relationship between its objective measurement and sensory assessment meat science. Meat Science 57(2): 157-159.

20. Simko P (2005) Factors affecting elimination of polycyclic aromatic hydrocarbons from smoked meat foods and liquid smoke flavourings. Mol nutr Food Res 49: 637-647.

21. Sogbesan OA, Sambo UM (2018) Determination of Benzo(a)pyrene Levels in Smoked Clarias gariepinus and Heterotis niloticus in Hadejia Jigawa State and Geriyo Adamawa State. Journal of Environmental Science and Public Health 1(3): 84-89.

22. Clucas IJ (1981) fish handling, processing and preservation in tropics In: Tropical product institute, Europe, pp.144.

23. Sogbesan O A, Aderolu AZ, Onwukike C, Ukaonu S, Maunde FA, et al. (2012) Preliminary evaluation of the efficiency of improved modern fish processor and Solar Tent Drier. Journal of Research in Science and Technology 1(6): 47-53.

24. Frazier W C, D C Westoff (1978) Food microbiology. In: $2^{\text {nd }}(e d n), M C$ Graw-Hill Pwb, NewDelhi, India, pp.160-163

25. Tabor J G (1985) Fish production and processing in Nigeria Ed. Journal $2(3): 51-56$ 